\title{
Analisis Ketelitian Penetuan Posisi Horizontal Menggunakan Antena GPS Geodetik Ashtech ASH111661
}

\author{
I Gede Brawiswa Putra, Mokhamad Nur Cahyadi \\ Jurusan Teknik Geomatika, Fakultas Teknik Sipil dan Perencanaan, Institut Teknologi Sepuluh Nopember \\ Jl. Arief Rahman Hakim, Surabaya 60111 Indonesia \\ e-mail: cahyadi@geodesy.its.ac.id
}

\begin{abstract}
Abstrak-GPS (Global Positioning System) adalah sistem navigasi radio dan penentuan posisi, yang biasa digunakan untuk pembuatan benchmark serta dalam pemantauan pergerakan jembatan. Seiring dengan meningkatnya pengguna teknologi GPS, saat ini banyak vendor GPS yang telah mengembangkan teknologi antena GPS dengan komponen dan tingkat kecanggihan yang berbeda, salah satunya adalah Ashtech. Ketelitian posisi pengamatan GPS akan tergantung pada jumlah satelit yang dapat diamati. Karena ketelitian merupakan hal yang penting dalam penentuan posisi, maka perlu dilakukan penelitian terhadap hal tersebut yang memungkinkan user/pengguna mendapatkan ketelitian dari titik pengamatan sesuai dengan tujuannya. Dalam penelitian ini, data yang digunakan adalah data pengukuran titik dengan metode kinematik di bentang tengah Jembatan Suramadu dan dengan metode statik di Institut Teknologi Sepuluh Nopember menggunakan antena GPS Geodetik Ashtech ASH111661. Pengukuran metode kinematik dan statik dilakukan selama selama 3 jam yang diikatkan dengan GPS Topcon GB 1000, terletak di lantai 4 gedung Teknik Geomatika ITS Surabaya. Data tersebut diolah menggunakan perangkat lunak ilmiah GAMIT 10.6. Kemudian dianalisis hasil dari pergerakan posisi titik yang diamati. Ketelitian posisi ditentukan dengan mempertimbangkan standar deviasi dan deformasi titik. Dari hasil analisa, pengukuran menggunakan antena GPS Ashtech ASH111661 menghasilkan standar deviasi 0.00343 m untuk pengukuran statik pada ruang terbuka, untuk standar deviasi pengukuran statik pada ruang tertutup sebesar $0.00199 \mathrm{~m}$, dan didapatkan selisih pengukuran deformasi Jembatan Suramadu sebesar 0.0199 m. Dari hasil uji statistik hasil pengukuran pada metode ruang terbuka tidak memiliki perbedaan yang signifikan pada metode statik. Sedangkan pada ruang tertutup, terdapat perbedaan yang signifikan dari hasil pengukuran Ashtech ASH111661 terhadap spesifikasi alatnya.
\end{abstract}

Kata Kunci-Antena GPS, Ashtech ASH111661, Deformasi, Standar deviasi

\section{PENDAHULUAN}

$\mathrm{S}$ EIRING dengan perkembangan dunia pemetaan dan meningkatnya pengguna teknologi GPS, pada saat ini banyak vendor GPS yang telah berkontribusi seperti beberapa merek yang beredar di pasaran salah satunya adalah Ashtech yang telah membuat dan mengembangkan teknologi antena GPS dengan tingkat kecanggihan komponen, harga, maupun jumlah sinyal satelit yang dapat diterima demikian pula dengan tingkat ketelitian yang diberikan. Ketelitian posisi yang didapat dengan pengamatan GPS akan tergantung pada ketelitian data yang digunakan [1]. Parameter yang mempengaruhi ketelitian data salah satunya adalah kualitas GPS yang digunakan. Dalam aplikasi pemetaan menggunakan GPS, ketelitian merupakan suatu pokok pembahasan yang sangat penting yaitu dalam penentuan posisi/kedudukan. Dengan memperhatikan kualitas dari antena GPS yang dapat mempengaruhi ketelitian posisi, maka perlu dilakukan suatu penelitian terhadap hal tersebut yang memungkinkan user/pengguna memperoleh titik yang memadai tentang ketepatan posisi tiga dimensi.

Alat yang digunakan pada tugas akhir ini adalah antena GPS Geodetik Ashtech ASH111661. Untuk melakukan analisis ketelitian penentuan posisi, dilakukan pengujian terhadap Jembatan Suramadu yang mengalami pergerakan tiap waktunya dengan metode kinematik dan terhadap benchmark di daerah kampus ITS Surabaya pada ruang terbuka yaitu lokasi yang terbebas dari multipath dan pada ruang tertutup yaitu lokasi yang dikelilingi oleh objek sperti gedung dan pohon dengan metode statik yang mempertimbangkan standar deviasi pengukuran dan deformasi jembatan. Sehingga diharapkan pada hasil penelitian dapat memberikan infomasi tentang besar perbedaan ketelitian posisi yang diberikan oleh alat jika dibandingkan dengan spesifikasinya dan gambaran sabagai acuan dalam pemilihan metode untuk penentuan posisi sesuai dengan obyek yang akan diukur.

\section{METODE PENELITIAN}

\section{A. Lokasi Pengamatan}

Lokasi penelitian tugas akhir ini adalah Jembatan Suramadu yang berada pada koordinat geografis $7^{\circ} 11^{\prime} 3^{\prime \prime}$ LS ; 112 $46^{\prime} 48^{\prime \prime}$ BT (titik di bentang tengah jembatan) dan dua titik benchmark di wilayah Institut Teknologi Sepuluh Nopember Surabaya dengan koordinat geografis $7^{\circ} 16^{\prime} 28^{\prime \prime L S} ; 112^{\circ} 47^{\prime} 52^{\prime \prime B T}$ dan $7^{\circ} 16^{\prime} 47^{\prime \prime} \mathrm{LS}$; $112^{\circ} 47^{\prime} 40^{\prime \prime B T}$.

B. Data

1. Pengamatan dua titik pada bentang tengah Jembatan Suramadu menggunakan GPS Geodetik Ashtech ASH111661 selama 3.5 jam.

2. Pengamatan titik pada ruang terbuka dan tertutup di kawasan ITS Surabaya menggunakan GPS Geodetik Ashtech ASH111661 selama 3 jam. 
3. Pengamatan titik dengan GPS Topcon GB 1000 yang terletak di lantai 4 gedung Teknik Geomatika ITS Surabaya.

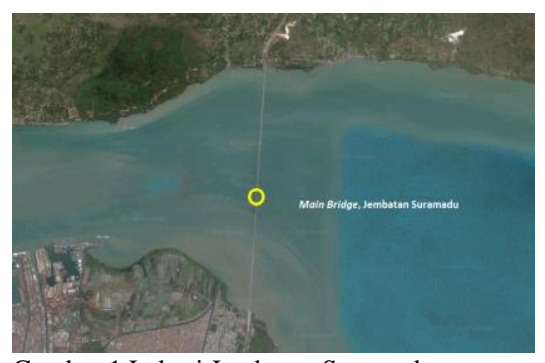

Gambar 1 Lokasi Jembatan Suramadu

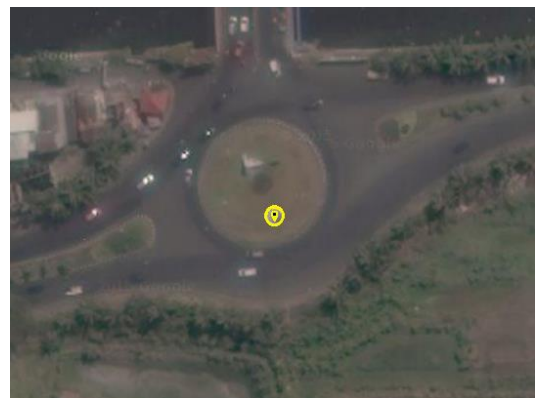

Gambar 2 Lokasi Pengamatan Titik di Ruang Terbuka

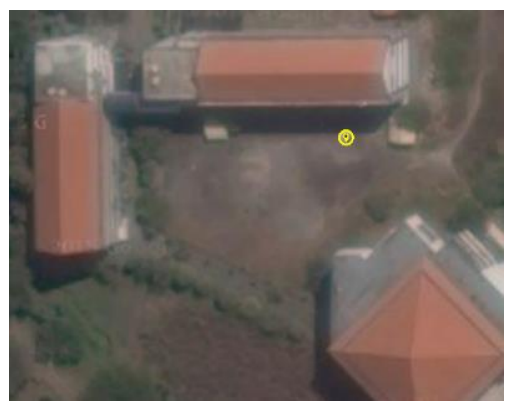

Gambar 3 Lokasi Pengamatan Titik di Ruang Tertutup

\section{Peralatan}

1. Antena GPS Geodetic Dual Frequency Ashtech ASH111661

2. GPS CORS Topcon GB1000

3. $A C C U$

4. Tribrach

5. Kabel Download

6. Personal Computer

7. Perangkat Lunak:
a. GNSS Solution
b. GAMIT 10.6
c. Rinex Converter

Tabel 1

Spesifikasi GPS Ashtech ASH111661 [2]

\begin{tabular}{ll}
\hline \hline & \multicolumn{1}{c}{ Spesifikasi } \\
\hline Deskripsi & S5 channel paralel terintegrasi \\
\hline & Spesifikasi Pelacakan \\
\hline \multirow{3}{*}{ Sinyal yang dilacak GLONASS; L1 C/A, P(Y)-code, full } \\
& $\begin{array}{l}\text { wavelength carrier; } \text { L2 P(Y)-code, L2C, L2 } \\
\text { full wavelength carrier; SBAS: } \\
\text { WAAS/EGNOS/MSAS }\end{array}$ \\
\hline & Spesifikasi Hasil \\
\hline
\end{tabular}

\begin{tabular}{ll}
\hline $\begin{array}{l}\text { Static post- } \\
\text { processing }\end{array}$ & $\mathrm{H}: 5 \mathrm{~mm}+1 \mathrm{ppm}$ \\
$\begin{array}{l}\text { Kinematic post- } \\
\text { processing }\end{array}$ & $\mathrm{H}: 12 \mathrm{~mm}+2 \mathrm{ppm}$ \\
RTK & $\mathrm{H}: 10 \mathrm{~mm}+1 \mathrm{ppm}$ \\
DGPS & $\mathrm{H}:<25 \mathrm{~cm}+1 \mathrm{ppm}$ \\
\hline \hline
\end{tabular}

D. Tahap Pengolahan Data

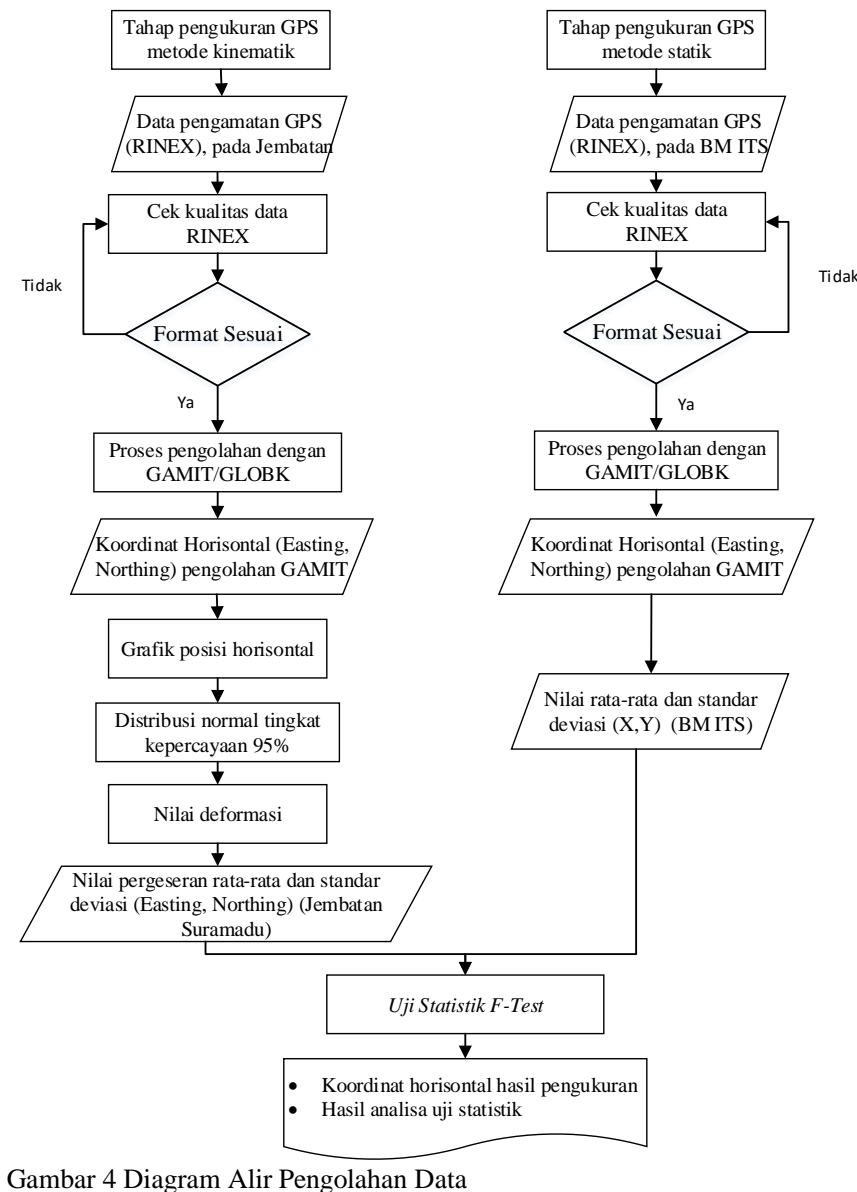

1. Data RINEX yang digunakan adalah data hasil pengukuran menggunakan GPS Ashtech ASH111661 selama 3 jam pada bentang tengah Jembatan Suramadu dengan metode kinematik dan 2 titik benchmark di kawasan ITS yang diamati dengan metode statik. Sebagai titik ikatnya digunakan data RINEX dari pengukuran GPS CORS Topcon GB1000 yang diamati selama rover melakukan pengambilan data.

2. Kemudian data hasil pengukuran dengan menggunakan GPS Ashtech dilakukan pengecekan kualitas data RINEX, dengan menginput tinggi alat, tipe antena dan receiver GPS sesuai dengan database tipe GPS pada software. Jika data RINEX telah sesuai dengan dengan spesifikasi alat dan database software maka dapat dilanjutkan ke pengolahan data GPS.

3. Pengolahan data GPS dilakukan dengan perhitungan post processing dengan perangkat lunak ilmiah GAMIT 10.6 untuk menghasilkan koordinat easting dan northing dari pengamatan dengan metode statik maupun kinematik.

4. Untuk data pengukuran pada Jembatan Suramadu dengan metode kinematik, setelah dihasilkan koordinat dari hasil 
post processing, kemudian dilakukan distribusi normal untuk menentukan nilai outlier atau nilai yang tidak memenuhi kriteria dengan menggunakan selang kepercayaan $95 \%$. Setelah melalui proses filter didapat nilai deformasi Jembatan Suramadu. Nilai deformasi didapat dari selisih posisi saat epok t dengan posisi rata-ratanya.

5. Hasil pengolahan data GPS dengan metode statik dan kinematik tersebut dibandingkan dengan spesifkasi alat menggunakan uji statistik chi-square. Uji ini digunakan untuk mengetahui ada atau tidaknya perbedaan antara suatu kelompok populasi dengan hipotesanya.

\section{HASIL DAN ANALISIS}

\section{A. Hasil Pengamatan GPS Metode Statik}

Pengolahan data GPS ini dilakukan menggunakan software GAMIT 10.6. Data yang diolah dalam penelitian ini adalah data pengamatan GPS dengan metode statik untuk lokasi terbuka yang terbebas dari multipath, dilakukan di kawasan ITS dan diikatkan pada GPS CORS ITS. Pengamatan GPS dilakukan dengan metode statik untuk lokasi tertutup yaitu lokasi titik yang sekitarnya dikelilingi oleh objek seperti gedung dan pohon yang dilakukan di Jurusan Teknik Geomatika ITS dan diikatkan pada GPS CORS ITS yang dilaksanakan pada tanggal 25 Februari 2015 dan 3 Maret 2016.

Tabel 2

Nilai Koordinat Metode Statik

\begin{tabular}{ccc}
\hline & Terbuka & Tertutup \\
\hline Easting & $698494.377 \mathrm{~m}$ & $698181.872 \mathrm{~m}$ \\
Northing & $9195498.88 \mathrm{~m}$ & $9194895.17 \mathrm{~m}$ \\
$\begin{array}{c}\text { Standar } \\
\text { Deviasi }\end{array}$ & $0.00343 \mathrm{~m}$ & $0.00423 \mathrm{~m}$ \\
\hline \hline
\end{tabular}

\section{B. Data Pengamatan GPS Jembatan Suramadu}

Pengukuran GPS pada Jembatan Suramadu dilaksanakan tanggal 2 Maret 2016, dilakukan pengukuran selama 3.5 jam pada bentang tengah Jembatan Suramadu (main bridge) dengan menggunakan Ashtech ASH111661 dengan metode kinematik yang diikatkan dengan local base yang didirikan pada pinggir Jembatan Suramadu. Kemudian local base tersebut diikatkan pada GPS CORS ITS. Berikut koordinat hasil pengukuran local base dan bentang tengah jembatan.

Tabel 3

Nilai Koordinat Local Base Suramadu

\begin{tabular}{lc}
\hline & Noordinat Local Base Suramadu \\
\hline \hline Easting & $696381.905 \mathrm{~m}$ \\
Northing & $9202797.795 \mathrm{~m}$ \\
Elevation & $-795041 \mathrm{~m}$ \\
\hline \hline
\end{tabular}

Tabel 4

Nilai Koordinat GPS Metode Kinematik

\begin{tabular}{cc}
\hline \hline Hasil Pengukuran Ashtech ASH111661 Metode Kinematik \\
\hline Mean Northing & $9205365.220 \mathrm{~m}$ \\
Mean Easting & $696592.173 \mathrm{~m}$ \\
Jumlah Data & 1382 \\
Variansi & $0.0024147 \mathrm{~m}^{2}$ \\
Standar Deviasi & $0.0577293 \mathrm{~m}$ \\
\hline \hline
\end{tabular}

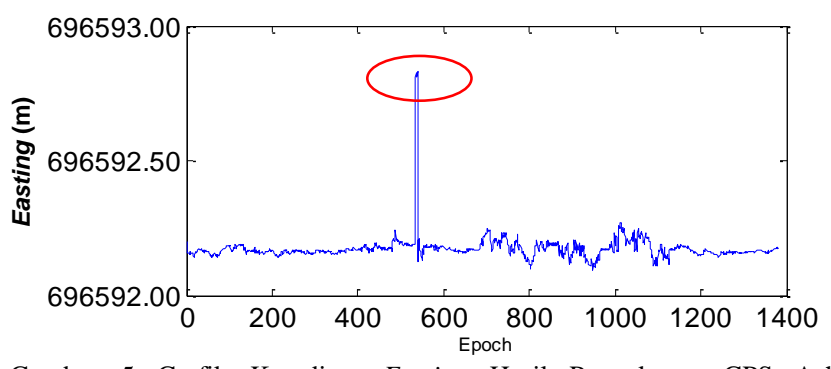

Gambar 5 Grafik Koordinat Easting Hasil Pengukuran GPS Ashtech ASH111661

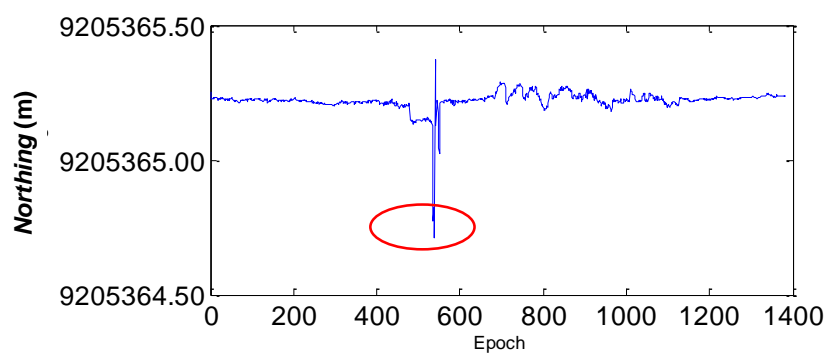

Gambar 6 Grafik Koordinat Northing Hasil Pengukuran GPS Ashtech ASH111661

Gambar 5 dan 6 menunjukkan data pengukuran GPS pada Jembatan Suramadu memiliki banyak noise dan terjadi cycle slips pada pengukuran dengan menggunakan antena GPS Ashtech ASH111661 terjadi loncatan koordinat yang jauh terhadap rata-rata. Hal ini terjadi dikarenakan banyal hal, yaitu letak titik pengamatan dekat dengan baja penyangga jembatan, pylon, dan tribrach yang tidak dapat mengunci dengan sempurna. Tingkat penyimpangan koordinat terhadap rataratanya yang ditunjukkan melalui nilai standar deviasi menunjukkan tingkat sebaran maksimum hingga level $\mathrm{cm}$.

\section{Analisis Hasil Pengukuran Metode Statik}

Perbandingan metode pengukuran statik dengan menggunakan antena Ashtech ASH111661 adalah dengan membandingkan antara nilai standar deviasi pengukuran dan spesifikasi yaitu sebesar $0.005 \mathrm{~m}$. Nilai selisih standar deviasi dapat dilihat pada tabel 5 .

Tabel 5

Perbandingan Koordinat Pengukuran Metode Statik

\begin{tabular}{ccc}
\hline & Terbuka & Tertutup \\
\hline Easting & $698494.377 \mathrm{~m}$ & $698181.872 \mathrm{~m}$ \\
Northing & $9195498.88 \mathrm{~m}$ & $9194895.17 \mathrm{~m}$ \\
Standar & $0.00343 \mathrm{~m}$ & $0.00423 \mathrm{~m}$ \\
$\begin{array}{c}\text { Deviasi } \\
\text { Selisih Stdv }\end{array}$ & $0.00157 \mathrm{~m}$ & 0.00077 \\
\hline \hline
\end{tabular}

Dari hasil pengukuran, didapatkan selisih nilai standar deviasi. Adanya nilai perbedaan tersebut disebabkan karena beberapa faktor seperti konfigurasi geometrik satelit yang kurang baik pada saat itu dan perbedaan jumlah sinyal satelit yang dapat diterima oleh masing-masing antena, kurang bebasnya pandangan receiver ke satelit sehingga mengganggu pengiriman sinyal, dan keterbatasan kemampuan antena.

Pada pengukuran di ruang terbuka, didapatkan total sinyal satelit yang dapat diterima adalah 13 satelit yang terdiri dari 13 satelit GPS dan 2 satelit SBAS. Sedangkan pada pengukuran di 
ruang tertutup, didapatkan total sinyal satelit yang dapat diterima adalah 11 satelit yang terdiri dari 11 satelit GPS dan 2 satelit SBAS.

Tabel 6

Paramater Hasil Pengukuran Orde GPS

\begin{tabular}{cc}
\hline \hline \multicolumn{2}{c}{ Pengukuran Orde } \\
\hline Jarak Baseline & $696.329 \mathrm{~m}$ \\
Nilai ppm & $4.925 \mathrm{ppm}$ \\
Tipe Receiver & Dual-Frekuensi \\
\hline \hline
\end{tabular}

Dari hasil pengukuran dengan metode statik ruang terbuka didapatkan nilai ppm lebih kecil dari 10 ppm, sehingga sesuai dengan standar orde pengukuran GPS, alat ini dapat digunakan untuk pengukuran orde 2 .

\section{Analisis Lokasi Pengamatan}

Berikut ini merupakan gambaran dari lokasi pengamatan GPS yang dijadikan sampel pada penelitian ini:

1. Ruang Terbuka

Lokasi : Jalan Raya ITS (Bundaran Mulyosari-ITS Pakuwon)

Lintang : : $7^{\circ} 16^{\prime} 28.61054^{\prime \prime S}$

Bujur $\quad: 112^{\circ} 47^{\prime} 52.47569^{\prime \prime} \mathrm{E}$

Tanggal Pengamatan : 24 dan 25 Februari 2016

Waktu Pengamatan : $11.00-14.00$ WIB

Lokasi pengamatan terletak di pinggir jalan, pandangan ke langit bebas gangguan, jarak dari bangunan terdekat sekitar 50 $\mathrm{m}$, pohon $30 \mathrm{~m}$, dan tiang listrik $35 \mathrm{~m}$. Karena lokasi pengamatan terletak dipinggir jalan, terdapat faktor getaran tanah yang dapat mempengaruhi hasil pengukuran yang disebabkan oleh banyaknya kendaraan yang melintas.

2. Ruang Tertutup

Lokasi : Lapangan Teknik Geomatika ITS

Lintang : : $7^{\circ} 16^{\prime} 47.95011 " \mathrm{~S}$

Bujur : : 112 $47^{\prime} 40.63943 " \mathrm{E}$

Tanggal Pengamatan : 3 dan 4 Maret 2016

Waktu Pengamatan : $10.10-13.20$ WIB

Lokasi pengamatan terletak di Lapangan Teknik Geomatika, dengan wilayah yang dikelilingi oleh gedung dan pohon. Jarak titik pengamatan dengan pohon terdekat sekitar 10 meter dan jarak titik pengamatan dengan gedung terdekat sekitar 4 meter dengan tinggi gedung mencapai 20 meter. Karena lokasi pengukuran dikelilingi objek seperti gedung dan pohon sehingga jumlah sinyal satelit yang dapat ditangkap oleh antena GPS berkurang dan dapat mempengaruhi hasil pengukuran.

\section{E. Analisis Perbandingan Koordinat Metode Kinematik}

Dari hasil didapat dari pengukuran pada Jembatan Suramadu dengan menggunakan antena GPS Ashtech ASH111661, dapat dilihat bahwa ada beberapa koordinat yang mengalami loncatan koordinat yang ekstrem (outlier) terhadap nilai rata-ratanya. jika dilakukan plotting data pengamatan fase terhadap waktu, maka cycle slip dapat dikenali dari loncatan mendadak kurva grafik [3]. Adanya outlier pada data ini disebabkan oleh cycle slip maupun multipath yang terjadi saat pengukuran. Untuk menghilangkan data yang berupa outlier digunakan suatu batas untuk menerima maupun menolak outlier tersebut. Dalam uji statistik dikenal distribusi normal, untuk mengetahui sebaran data hasil pengukuran. Distribusi normal memiliki parameter distribusi yaitu rata-rata (mean $\mu$ ) dan standar deviasi (standard deviation $\sigma$ ). Untuk nilai tingkat kepresisian pengukuran, digunakan tingkat kepercayaan $95 \%$.

\section{F. Filtering Data}

Filtering data koordinat horizontal jembatan hasil pengukuran dengan menggunakan antena GPS Ashtech ASH111661 digunakan uji statistik tingkat kepercayaan 95\%. Hal ini berarti nilai yang kurang dari batas bawah dan nilai yang lebih dari batas atas akan direduksi.

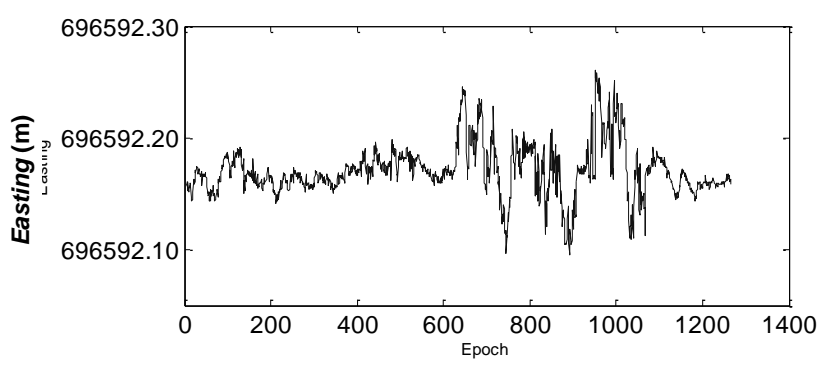

Gambar 7 Grafik nilai koordinat Easting Ashtech ASH111661 pada Jembatan Suramadu setelah filtering

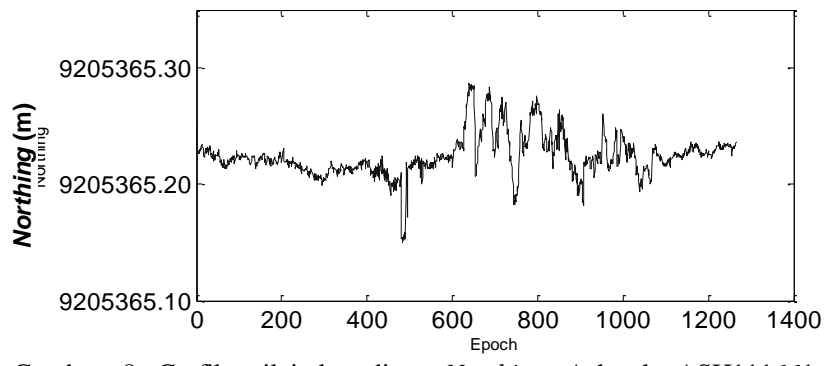

Gambar 8 Grafik nilai koordinat Northing Ashtech ASH111661 pada Jembatan Suramadu setelah filtering

Tabel 7

Perubahan Nilai Koordinat Easting Setelah Filtering

\begin{tabular}{cccc}
\hline \hline Data Statistik & $\begin{array}{c}\text { Setelah } \\
\text { Filtering }\end{array}$ & $\begin{array}{c}\text { Sebelum } \\
\text { Filtering }\end{array}$ & \multirow{2}{*}{ Selisih } \\
\hline Max Easting & $696592.261 \mathrm{~m}$ & $696592.8290 \mathrm{~m}$ & $0.568 \mathrm{~m}$ \\
Min Easting & $696592.095 \mathrm{~m}$ & $696592.0950 \mathrm{~m}$ & $0 \mathrm{~m}$ \\
Rata-rata & $696592.170 \mathrm{~m}$ & $696592.1736 \mathrm{~m}$ & $0.0036 \mathrm{~m}$ \\
Standar Deviasi & $0.0226 \mathrm{~m}$ & $0.0452 \mathrm{~m}$ & $0.0226 \mathrm{~m}$ \\
\hline \hline
\end{tabular}

Tabel 8

Perubahan Nilai Koordinat Northing Setelah Filtering

\begin{tabular}{cccc}
\hline Data Statistik & $\begin{array}{c}\text { Setelah } \\
\text { Filtering }\end{array}$ & $\begin{array}{c}\text { Sebelum } \\
\text { Filtering }\end{array}$ & \multirow{2}{*}{ Selisih } \\
\hline Max Northing & $9205365.287 \mathrm{~m}$ & $9205365.373 \mathrm{~m}$ & $0.086 \mathrm{~m}$ \\
Min Northing & $9205365.150 \mathrm{~m}$ & $9205364.709 \mathrm{~m}$ & $-0.441 \mathrm{~m}$ \\
Rata-rata & $9205365.225 \mathrm{~m}$ & $9205365.220 \mathrm{~m}$ & $-0.0049 \mathrm{~m}$ \\
Standar Deviasi & $0.0179 \mathrm{~m}$ & $0.0360 \mathrm{~m}$ & $0.0181 \mathrm{~m}$ \\
\hline \hline
\end{tabular}

\section{G. Analisis Deformasi Jembatan Suramadu}

Analisis deformasi yang digunakan adalah analisis pergeseran posisi jembatan terhadap posisi sebenarnya (ratarata posisi jembatan dari hasil pengukuran dianggap posisi sebenarnya). Analisis pergeseran ini merupakan salah satu metode untuk mengetahui deformasi melalui analisis geometrik 
(nilai ini didapatkan dari rata-rata fluktuasi pergerakan koordinat terhadap rata-rata).

Tabel 9

Nilai Deformasi Jemabatan Suramadu

\begin{tabular}{ll}
\hline \hline \multicolumn{2}{c}{ Nilai Deformasi } \\
\hline Easting & $0.0156 \mathrm{~m}$ \\
Northing & $0.0125 \mathrm{~m}$ \\
Pergeseran Posisi Total & $0.0199 \mathrm{~m}$ \\
\hline \hline
\end{tabular}

Tabel 9 menunjukkan bahwa kisaran nilai deformasi pada hasil pengukuran dengan menggunakan antena Ashtech ASH111661 berada pada level cm, dan masih berada dalam batas toleransi nilai pergeseran horizontal dari Jembatan Suramadu.

\section{H. Uji Statistik}

Pada uji statistik ini digunakan uji Chi-aquare untuk mengetahui kesesuaian hasil pengukuran dengan spesifikasi awal dari kedua alat yang digunakan. Uji ini dilakukan dengan membandingkan variansi kedua hasil pengolahan dari pengukuran dengan variansi spesifikasi alat pada metode statik pada lokasi ruang terbuka, dan metode statik pada lokasi ruang tertutup. Hipotesa nol yang digunakan pada uji statistik ini adalah hasil pengolahan tidak terdapat perebedaan yang signifikan sehingga:

$$
\begin{array}{ll}
\text { Hipotesa nol } & \mathrm{H}_{0}: \sigma_{2}=0.000025 \\
\text { Hipotesa alternatif } & \mathrm{H}_{0}: \sigma_{2} \neq 0.000025 \\
X_{c h i 1-\frac{\alpha}{2}, v 1, v 2}^{2}<X_{c h i}^{2}=\frac{(n-1) S_{1}^{2}}{\sigma_{2}^{2}}<X_{c h i}^{2} \frac{\alpha, v 1, v 2}{2^{2}} \\
X_{c h i}^{2}=\frac{(n-1) S_{1}^{2}}{\sigma_{2}^{2}}>X_{c h i}^{2} \\
X_{c h i}^{2}=\frac{(n-1) S_{1}^{2}}{\sigma_{2}^{2}}<X_{c h i}^{2}{ }_{1-\frac{\alpha}{2}, v 1, v 2}
\end{array}
$$

Uji Chi-aquare dapat dihitung dan dianalisis dengan selang kepercayaan $95 \%$, pada metode statik ruang terbuka, metode statik ruang tertutup, dan metode kinematik. Hasil uji statistik dapat dikatakan tidak signifikan apabila memenuhi syarat seperti (1). Hasil uji statistik dapat dikatakan signifikan apabila hasil uji statistik seperti (2) dan (3).

Tabel 10

Nilai Variansi Pengukuran

\begin{tabular}{ccc}
\hline Metode & $\begin{array}{c}\text { Variansi } \\
\text { Ashtech }\left(\mathbf{S}_{\mathbf{1}}\right)\end{array}$ & $\begin{array}{c}\text { Variansi } \\
\text { Spesifikasi }\left(\mathbf{S}_{\mathbf{2}}\right)\end{array}$ \\
\hline Statik, Ruang Terbuka & $0.00003364 \mathrm{~m}^{2}$ & $0.000025 \mathrm{~m}^{2}$ \\
Statik, Ruang Tertutup & $0.00006241 \mathrm{~m}^{2}$ & $0.000025 \mathrm{~m}^{2}$ \\
Kinematik & $0.00083002 \mathrm{~m}^{2}$ & $0.000144 \mathrm{~m}^{2}$ \\
\hline \hline
\end{tabular}

Pada tabel 10 didapatkan nilai variansi pengukuran dari masing-masing alat pada tiap metode pengukuran, maka dari nilai veriansi tersebut dihasilkan nilai $X^{2}$ chi hitung yang ditunjukkan pada tabel 11 .
Tabel 11

Hasil Uji Statistik

\begin{tabular}{cccc}
\multicolumn{4}{c}{ Hasil Uji Statistik } \\
\hline \hline Metode & $\mathbf{X}_{\text {chi }}$ Hitung & $\mathbf{F}_{\mathbf{1 - \alpha / 2}}$ & $\mathbf{F}_{\mathbf{\alpha} / \mathbf{2}}$ \\
\hline Statik, Ruang Terbuka & 2.596 & 3.816 & 21.920 \\
Statik, Ruang Tertutup & 3.082 & 3.816 & 21.920 \\
Kinematik & 5.764 & 1225.05 & 1426.74 \\
\hline \hline
\end{tabular}

Dari hasil uji statistik, didapatkan bahwa pada metode statik ruang terbuka menunjukkan nilai $\mathrm{X}_{\text {chi 1- } \alpha / 2}$ tabel $<\mathrm{X}_{\text {chi }}^{2}$ hitung $<$ $\mathrm{X}_{\text {chi } \alpha / 2}$ tabel, sehingga diketahui hasil pengukuran metode statik dengan menggunakan kedua alat tersebut tidak terdapat perbedaan yang signifikan.

Sedangkan pengukuran dengan metode kinematik dan statik pada ruang tertutup dari hasil uji statistik menunjukkan nilai $\mathrm{X}^{2}$ chi hitung $>\mathrm{X}_{\text {chi }}^{2}$ tabel, sehingga diketahui hasil pengukuran metode kinematik dengan menggunakan kedua alat tersebut terdapat perbedaan.

\section{KESIMPULAN}

1. Dalam pengukuran metode statik di ruang terbuka Didapatkan nilai standar deviasi hasil pengukuran dengan menggunakan antena GPS Ashtech ASH111661 sebesar $0.00343 \mathrm{~m}$, dan selisih standar deviasinya terhadap spesifikasi sebesar $0.00157 \mathrm{~m}$. Dari hasil uji statistik, tidak terdapat perbedaan yang signifikan antara hasil pengukuran dan spesifikasi alat.

2. Dalam pengukuran metode statik di ruang tertutup didapatkan nilai standar deviasi hasil pengukuran dengan menggunakan antena GPS Ashtech ASH111661 sebesar $0.00423 \mathrm{~m}$, dan selisih standar deviasinya terhadap spesifikasi sebesar $0.00077 \mathrm{~m}$. Dari hasil uji statistik, terdapat perbedaan yang signifikan antara hasil pengukuran dan spesifikasi alat pada selang kepercayaan $95 \%$.

3. Dalam pengukuran metode kinematik didapatkan nilai pergeseran dari hasil pengukuran dengan menggunakan antena GPS Ashtech ASH111661 sebesar 0.0199 m. Dari hasil uji statistik, terdapat perbedaan yang signifikan antara hasil pengukuran dan spesifikasi alat pada selang kepercayaan $95 \%$.

4. Adanya perbedaan hasil yang signifikan dari pengukuran menggunakan antena Ashtech ASH111661 dengan spesifikasinya dikarenakan banyal hal, antara lain karena letak titik pengamatan dekat dengan baja penyangga jembatan, pylon, dan tribrach yang tidak dapat mengunci dengan sempurna.

\section{UCAPAN TERIMA KASIH}

Penulis I G.B.P. mengucapkan terima kasih kepada PT. Adhimulya Interniagatama atas kesediaannya mengizinkan penulis menggunakan GPS Ashtech dalam penelitian ini, dan kepada Badan Suramadu Health Monitoring System (SHMS) yang telah mengizinkan penulis melakukan pengukuran di Jembatan Suramadu. 


\section{DAFTAR PUSTAKA}

[1] Abidin, H. Z. (2002). Survei Dengan GPS. Jakarta: PT Pradnya Paramita.

[2] Ashtech. (2010). Ashtech Antena. Retrieved from Spectra Precision, Ashtech, Magellan Professional, Thales GPS Equipment and Support Software: $\quad$ ashgps.com/mirror/master/ProMark\%20120220/Hardware/ASH111661.pdf

[3] Nugraini, L. D. (2011). Analisis Deformasi Jembatan Suramadu Akibat Pengaruh Angin Menggunakan Pengukuran GPS Kinematik. Surabaya: Institut Teknologi Sepuluh Nopember. 